\title{
Equilibrium and kinetic studies of copper biosorption by dead Ceriporia lacerata biomass isolated from the litter of an invasive plant in China
}

\author{
Xiaona $\mathrm{Li}^{1,2,4}$, Airong $\mathrm{Li}^{5}$, Mingzhong Long ${ }^{6}$ and Xingjun Tian ${ }^{1,3^{*}}$
}

\begin{abstract}
Background: Ceriporia lacerata, a strain of white-rot fungus isolated from the litter of an invasive plant (Solidago canadensis) in China, was little known about its properties and utilization. In this work, the copper(II) biosorption characteristics of formaldehyde inactivated C. lacerata biomass were examined as a function of initial pH, initial copper(II) concentration and contact time, and the adsorptive equilibrium and kinetics were simulated, too.

Results: The optimum pH was found to be 6.0 at experimental conditions of initial copper(II) concentration $100 \mathrm{mg} / \mathrm{L}$, biomass dose $2 \mathrm{~g} / \mathrm{L}$, contact time $12 \mathrm{~h}$, shaking rate $150 \mathrm{r} / \mathrm{min}$ and temperature $25^{\circ} \mathrm{C}$. Biosorption equilibrium cost about 1 hour at experimental conditions of $\mathrm{pH} 6.0$, initial copper(II) concentration $100 \mathrm{mg} / \mathrm{L}, \mathrm{C}$. lacerata dose $2 \mathrm{~g} / \mathrm{L}$, shaking rate $150 \mathrm{r} / \mathrm{min}$ and temperature $25^{\circ} \mathrm{C}$. At optimum pH 6.0, highest copper(II) biosorption amounts were 6.79 and $7.76 \mathrm{mg} / \mathrm{g}$ for initial copper(II) concentration of 100 and $200 \mathrm{mg} / \mathrm{L}$, respectively (with other experimental parameters of C. lacerata dose $2 \mathrm{~g} / \mathrm{L}$, shaking rate $150 \mathrm{r} / \mathrm{min}$ and temperature $25^{\circ} \mathrm{C}$ ). The pseudo second-order adsorptive model gave the best adjustment for copper(II) biosorption kinetics. The equilibrium data fitted very well to both Langmuir and Freundlich adsorptive isotherm models.
\end{abstract}

Conclusions: Without further acid or alkali treatment for improving adsorption properties, formaldehyde inactivated $C$. lacerata biomass possesses good biosorption characteristics on copper(II) removal from aqueous solutions.

Keywords: Ceriporia lacerata, Biosorption, Copper, Adsorption isotherm, Kinetics

\section{Background}

Heavy metal pollution is an increasing environmental problem of worldwide concern. Reducing heavy metals to environmentally acceptable limits in a cost-effective, easily available and environmental friendly manner becomes more and more urgent $[1,2]$. Biosorption of heavy metals from wastewaters by pretreated fungal biomass has gained growing acceptance since the 1990s [3,4].

The heavy metal ion biosorption by fungal biomass is based mainly on two mechanisms: covalent bonding with functional groups including carboxyl, hydroxyl, phosphate, amino, sulphydryl, and the result of physicochemical inorganic interactions directed by adsorption phenomena [2,5-7]. Therefore, here are several critical

\footnotetext{
* Correspondence: tianxj@nju.edu.cn

'School of Life Science, Nanjing University, Nanjing 210093, China

${ }^{3}$ Co-Innovation Center for Sustainable Forestry in Southern China, Nanjing

Forestry University, Nanjing 210037, China
}

Full list of author information is available at the end of the article parameters affecting biosorption characteristics, such as $\mathrm{pH}$, pretreatment methods, metal species, initial concentration of solutions, quantity of biomass, contact time [8-10].

Many fungi have been extensively studied and proved to be good biosorbents of heavy metals, such as Rhizopus arrhizus [11-14], Aspergillus spp. [6,15-17], Penicillium spp. [17,18] and Saccharomyces spp. [2,19]. However, white-rot fungi were relatively less reported for their biosorption though they were strong degrader of various xenobiotics and detoxicating materials of contaminated effluents $[20,21]$. They also possess the capacity of heavy metal biosorption [21].

Ceriporia lacerata is a white-rot fungus first isolated as a new species from white-rotted wood in Japan [22]. Till 2006, only four other reports published about it, referring to its taxonomy, genetics or decomposition [23-25]. Since 2007, C. lacerata has been more widely researched on its clinical significance, wood-decaying 
effect, metal tolerance and sorption potential and some other characteristics [26-30]. Kim et al. [31] found that the cadmium(II) removal rates by $C$. lacerata in stationary and shaking cultures were about $7 \%$ and $11 \%$, respectively. However, there is so limited information yet available on this species that its other properties need further study. The objectives of this work were to verify the capacity of dead C. lacerata in copper(II) removal under batch conditions, to determine the influences of parameters involved, and to simulate the adsorptive equilibrium and kinetics.

\section{Materials and methods}

\section{Preparation of the biomass}

Fungus C. lacerata was isolated from the litter of Solidago canadensis (an exotic plant to China) in Pukou, Nanjing, China. It was cultivated at $25^{\circ} \mathrm{C}$ in $250 \mathrm{~mL}$ flasks containing $100 \mathrm{~mL}$ liquid medium composed of malt extract $(20 \mathrm{~g} / \mathrm{L})$, peptone $(1 \mathrm{~g} / \mathrm{L})$ and dextrose $(20 \mathrm{~g} / \mathrm{L})$. After about 10 days incubation on a shaker at $150 \mathrm{r} / \mathrm{min}$, C. lacerata mycelium was washed several times with deionized water, and then inactivated by immersion into $1 \%$ formaldehyde. After washing, the mycelium was dried at $60^{\circ} \mathrm{C}$ for 24 hour (h). Finally, dry mycelium was ground and sieved (mesh size $<0.5 \mathrm{~mm}$ ).

\section{Metal solutions}

Copper(II) solutions of 5 to $300 \mathrm{mg} / \mathrm{L}$ were obtained by diluting copper(II) stock solution $(1 \mathrm{~g} / \mathrm{L})$, which was prepared by dissolving $\mathrm{CuCl}_{2} \cdot 2 \mathrm{H}_{2} \mathrm{O}$ (analytical reagent grade, Shanghai Zhenxing Chemical Reagent Factory, China) in deionized water. Solution $\mathrm{pH}$ was adjusted with $0.1 \mathrm{~mol} / \mathrm{L} \mathrm{HCl}$ and $\mathrm{NaOH}$ and measured by $\mathrm{pH}$ meter (PHS-3C, Shanghai Hongyi Instrumentation Co., Ltd, China).

\section{Batch biosorption experiments}

Batch biosorption experiments were conducted separately to evaluate the effects of $\mathrm{pH}$, time, initial copper(II) concentration on biosorption of copper ions. All experiments were performed in duplicate, and the mean values were taken as the final results. For every treatment, $0.2 \mathrm{~g}$ dead biomass was added into $100 \mathrm{~mL}$ of copper(II) solution in $250 \mathrm{~mL}$ flask. The flasks were shaken $(150 \mathrm{r} / \mathrm{min})$ at $25^{\circ} \mathrm{C}$ for $12 \mathrm{~h}$. Then, copper(II) solutions were vacuum filtered through Millipore membrane filters $(0.45 \mu \mathrm{m}$, Shanhai Xingya Purification Material Factory, China). After dilution, initial and equilibrium copper(II) concentrations were determined using an atomic absorption spectrometer (AA320CRT, Shanghai Analytical Instrument Overall Factory, China). The copper(II) biosorption amount was calculated by Eq. (1):

$$
q_{e}=\frac{V\left(C_{0}-C_{e}\right)}{m}
$$

where $q_{e}(\mathrm{mg} / \mathrm{g})$ is the amount of copper(II) adsorbed on per gram of biosorbent, $V(\mathrm{~L})$ is the volume of copper(II) solution in the flasks, $C_{O}$ and $C_{e}(\mathrm{mg} / \mathrm{L})$ are the initial and equilibrium copper(II) concentration, respectively, and $m(\mathrm{~g})$ is the dry weight of dead C. lacerata biomass.

Experiments to evaluate the effect of $\mathrm{pH}$ on biosorption were conducted constantly at $\mathrm{pH} 2.5$ to 7.0 , with intervals of 0.5 , while initial copper(II) concentration was $100 \mathrm{mg} / \mathrm{L}$.

Experiments to analyze the effect of contact time were operated at optimum $\mathrm{pH}$ and copper(II) concentration of $100 \mathrm{mg} / \mathrm{L}$. Samples were harvested at 1/12, 1/6, 1/4, $1 / 2,1,2,4,6,8$ and $12 \mathrm{~h}$.

Experiments to analyze the effect of initial sorbate concentration were performed at $5,10,25,50,75,100$, 200 and $300 \mathrm{mg} / \mathrm{L}$ (at optimum pH).

\section{Biosorption kinetics analysis}

Kinetic models can simulate the data of contact time experiments. This study was simulated by both the linear first-order Lagergren (Eq. (2)) and pseudo second-order (Eq. (3)) models [6,32-34]:

$$
\begin{aligned}
& \ln \left(q_{e}-q_{t}\right)=\ln q_{e}-k^{\prime} t \\
& \frac{t}{q_{t}}=\left(\frac{1}{q_{e}}\right) t+\frac{1}{2 k_{P} q_{e}{ }^{2}}
\end{aligned}
$$

where $k^{\prime}\left(\mathrm{h}^{-1}\right)$ and $k_{P}(\mathrm{~g} / \mathrm{mg} \cdot \mathrm{h})$ are the first and second-order rate constants, respectively, $q_{e}$ and $q_{t}$ are the amounts of copper entrapped on per gram of biosorbent $(\mathrm{mg} / \mathrm{g})$ at equilibrium and time $t(\mathrm{~h})$, respectively.

\section{Biosorption isotherm analysis}

Experiments to evaluate the effect of initial sorbate concentration were also used for biosorption isotherm studies. Langmuir and Freundlich isotherms were used to simulate the experimental data from the batch system at $25^{\circ} \mathrm{C}$.

The linear Langmuir isotherm equation is:

$$
\frac{1}{q_{e}}=\frac{1}{q_{\max }}+\left(\frac{1}{q_{\max } K_{L}}\right) \frac{1}{C_{e}}
$$

where $q_{\max }$ (maximum possible amount of copper adsorbed on per gram of biosorbent, $\mathrm{mg} / \mathrm{g}$ ) is the monolayer biosorption capacity of the biomass, and $K_{L}$ is the Langmuir adsorption constant $(\mathrm{L} / \mathrm{mg})[21,35]$. The equation of the Freundlich model is: 


$$
q_{e}=K_{F} C_{e}{ }^{n}
$$

where $K_{F}$ and $n$ are Freundlich adsorption constants and they respectively indicate adsorption capacity and intensity $[10,36]$.

\section{Results and discussion}

\section{Effect of $\mathrm{pH}$ on biosorption}

Copper(II) biosorption capacity of dead C. lacerata biomass at different $\mathrm{pH}$ is shown in Figure 1. Approximately, the biosorption capacity of biomass increased with an increase of $\mathrm{pH}$ from 2.5 to 6.0, and then decreased at $\mathrm{pH} 6.5$ and 7.0. Additionally, during the adsorptive process, the $\mathrm{pH}$ of equilibrium solution was slightly lower than that of initial solution.

Previous studies showed that $\mathrm{pH}$ value of the solution was an important parameter for both solution chemical properties of metals and surface characteristics of biosorbents [37-41]. According to Asmal et al. [42], there are three species of copper present in solution: $\mathrm{Cu}^{2+}, \mathrm{CuOH}^{+}$ and $\mathrm{Cu}(\mathrm{OH})_{2}$. At low $\mathrm{pH}$ (here maybe from 2.5 to 3.5), $\mathrm{H}^{+}$ ions competed with $\mathrm{Cu}^{2+}$ ions for the biosorption sites, that is protonation of the cell wall components negatively affected the biosorption capacity of dead C. lacerata biomass. However, this effect became less with the increase in $\mathrm{pH}$ (from 4.0 to 6.0 ) owing to that the raise of negative charges density on the cell surface offered more metal binding sites $[6,7,15]$. At this $\mathrm{pH} \mathrm{Cu}{ }^{2+}$ and $\mathrm{CuOH}^{+}$were more favourable copper species. Therefore, just like the results of some works [6,43-45], we also found a sharp increase in biosorption with a slight increase of $\mathrm{pH}$ (at around $\mathrm{pH}$ 3.5). At higher $\mathrm{pH}(\geq 6.5)$, precipitation of copper(II) hydroxide occurred and precipitated on surfaces of biomass and bottle wall. Furthermore, all those above suggested that ion-exchange played an important role in biosorption of copper(II) ions by dead C. lacerata.

The optimum $\mathrm{pH}$ was 6.0 at which copper(II) biosorption capacity of dead $C$. lacerata biomass reached $6.79 \mathrm{mg} / \mathrm{g}$. The optimum $\mathrm{pH}$ values of different reports on copper(II) biosorption by different biomasses differ quite a bit. Phanerochaete chrysosporium fungal biomasses $[7,40]$ and three species of dead fungal biomasses (Cladosporium cladosporioides, Gliomastix murorum and Bjerkandera sp.) [46] showed the same optimum $\mathrm{pH} 6.0$ for copper(II) removal, while cone biomass of Thuja orientalis showed the optimum $\mathrm{pH}$ value to be 7.7 [47] and Chlorella vulgaris algal biomass to be 5.0. The components and structural characteristics of various biomasses are quite diverse, which may be the most important reason for optimum $\mathrm{pH}$ differences. There must be other reasons such as different experimental parameters and operating error.

\section{Effect of contact time on biosorption}

At optimum $\mathrm{pH}$, the amount of copper(II) adsorbed by dead $C$. lacerata increased during the biosorption process (Figure 2). This process consisted of two phases: the rapid phase during the first one hour at which biosorption contributed significantly great to adsorptive equilibrium, and the subsequent slower phase when biosorption contributed relatively small. At the end of the rapid phase, the amount of copper(II) biosorption reached $86 \%$ of the equilibrium which cost about 1 hour. The copper(II) biosorption decreased at the 2nd and 4th hours might because at that time the slightly decrease of $\mathrm{pH}$ resulted in $\mathrm{H}^{+}$ions competing slightly with $\mathrm{Cu}^{2+}$ and $\mathrm{CuOH}^{+}$ions for the biosorption sites and/or because of experimental errors, which needs to be further studied.

The equilibrium time of the copper biosorption by fungal biomass is determined by many parameters such

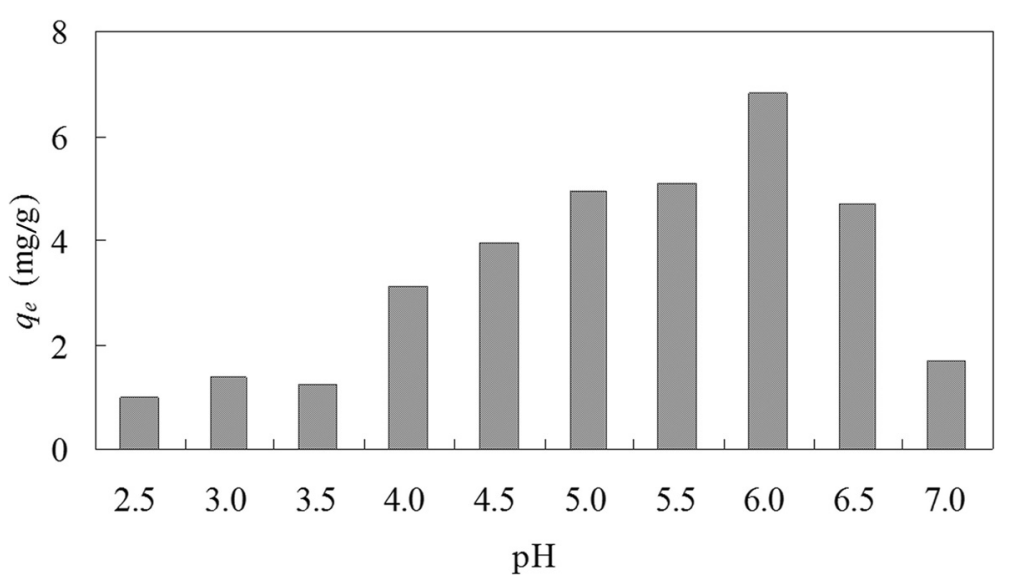

Figure 1 The effect of solution pH on copper biosorption by Ceriporia lacerata. Experimental conditions: initial copper(II) concentration $=100$ $\mathrm{mg} / \mathrm{L}$, volume of copper(II) solution $=100 \mathrm{~mL}$, Ceriporia lacerata dose $=2 \mathrm{~g} / \mathrm{L}$, contact time $=12 \mathrm{~h}$, shaking rate $=150 \mathrm{r} / \mathrm{min}$, temperature $=25^{\circ} \mathrm{C}$. 


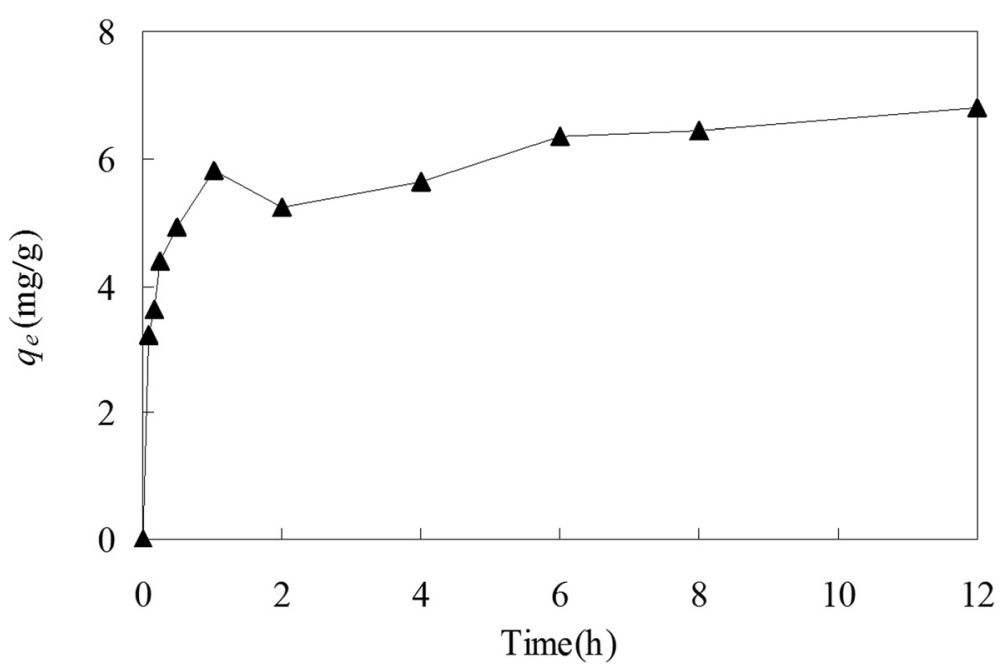

Figure 2 The amount of copper biosorption by Ceriporia lacerata at different contact time. Experimental conditions: pH 6.0, initial copper(II) concentration $=100 \mathrm{mg} / \mathrm{L}$, volume of copper $(I I)$ solution $=100 \mathrm{~mL}$, Ceriporia lacerata dose $=2 \mathrm{~g} / \mathrm{L}$, shaking rate $=150 \mathrm{r} / \mathrm{min}$, temperature $=25^{\circ} \mathrm{C}$.

as agitation rate of the solution, pretreated methods of the fungal biomass, structural properties and quantity of the biosorbents, the existence of other metal ions and initial copper(II) concentration [21]. Therefore, one species of biosorbent may cost different time (ranging from a few minutes to several hours $[7,14,48]$ ) to reach equilibrium under different conditions. One hour as the equilibrium time of copper biosorption in this study was scarcely reported before.

\section{Effect of initial copper(II) concentration on biosorption} The effect of initial copper(II) concentration on biosorption is presented in Figure 3. Approximately, copper biosorption increased with the increase of initial copper(II) ion concentration at the same unprecipitable $\mathrm{pH}$. At $\mathrm{pH}$ 6.0, copper biosorption capacity increased sharply from $0.85 \mathrm{mg} / \mathrm{g}$ to $6.79 \mathrm{mg} / \mathrm{g}$ (Figure 3) while the initial copper(II) concentration was from 5 to 100 $\mathrm{mg} / \mathrm{L}$, but this increase became minor if the initial concentration continued to be raised. The highest biosorption capacity was $7.76 \mathrm{mg} / \mathrm{g}$ for $200 \mathrm{mg} / \mathrm{L}$ at $\mathrm{pH} 6.0$.

At $\mathrm{pH}$ 6.0, copper(II) precipitated at initial concentrations higher than $300 \mathrm{mg} / \mathrm{L}$. Under the same conditions, in the solutions of higher concentration, there were much more copper(II) ions around the active sites of C. lacerata biomass. Thus the adsorptive process could proceed more

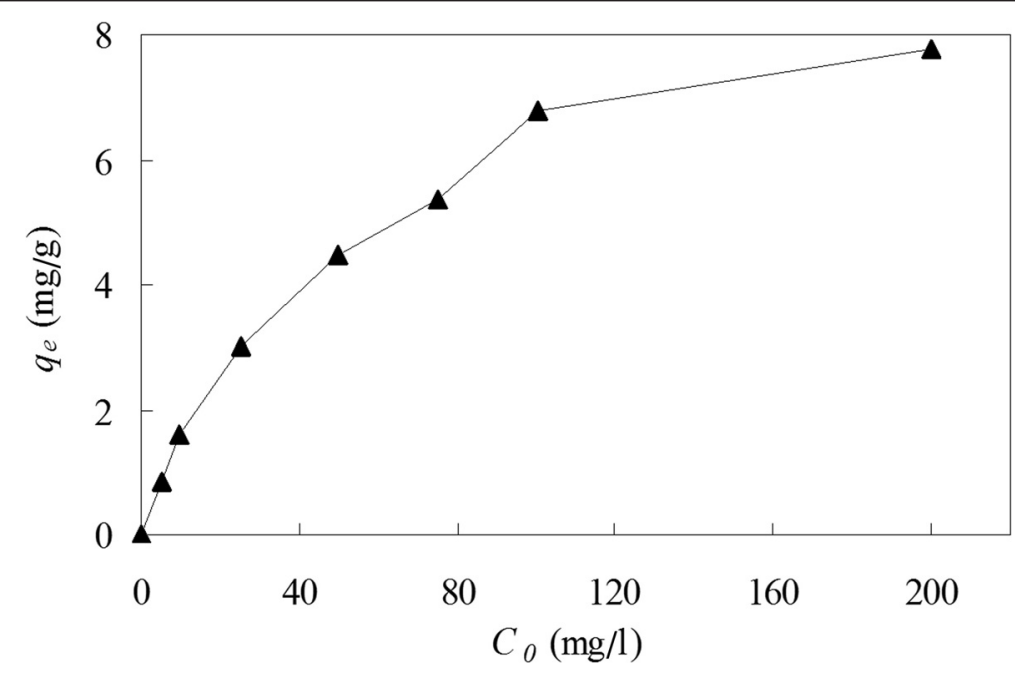

Figure 3 The effect of initial copper(II) concentration on copper biosorption by Ceriporia lacerata at optimum pH 6.0. Experimental conditions: $\mathrm{pH}$ 6.0, volume of copper(II) solution $=100 \mathrm{~mL}$, Ceriporia lacerata dose $=2 \mathrm{~g} / \mathrm{L}$, contact time $=12 \mathrm{~h}$, shaking rate $=150 \mathrm{r} / \mathrm{min}$, temperature $=25^{\circ} \mathrm{C}$. 


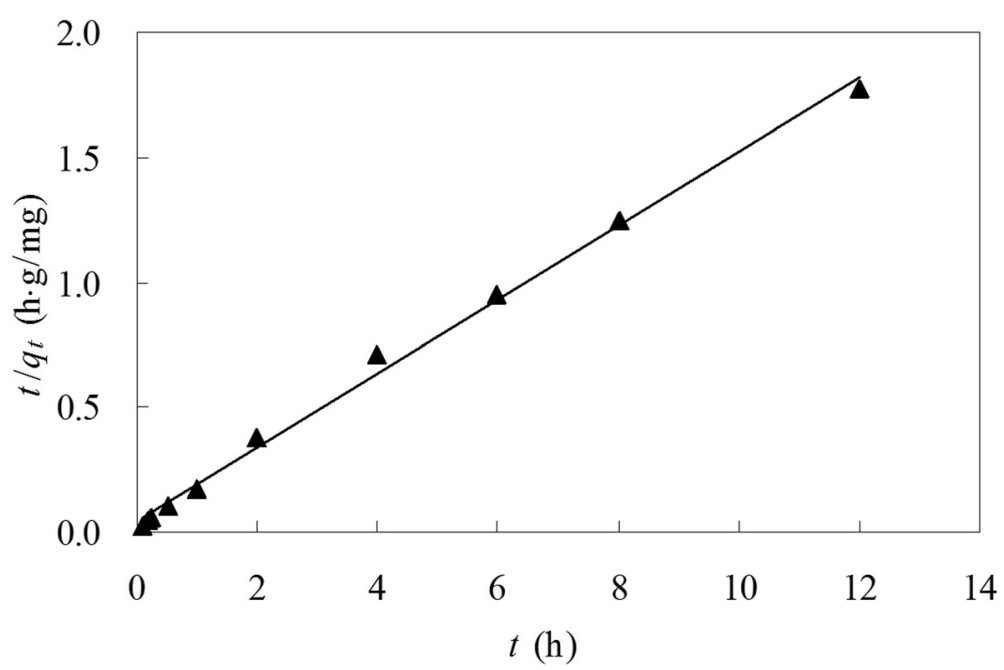

Figure 4 Linear plot of the pseudo second-order equation for copper biosorption by Ceriporia lacerata. Experimental conditions: pH 6.0, initial copper (II) concentration $=100 \mathrm{mg} / \mathrm{L}$, volume of copper $($ II) solution $=100 \mathrm{~mL}$, Ceriporia lacerata dose $=2 \mathrm{~g} / \mathrm{L}$, contact time $=12 \mathrm{~h}$, shaking rate $=150 \mathrm{r} / \mathrm{min}$, temperature $=25^{\circ} \mathrm{C}$.

sufficiently, and that is why copper(II) adsorptive capacity increased with the increasing of initial concentration.

\section{Biosorption kinetics}

Mathematical models could be used for the quantitative description of the kinetic results. There were two kinetic equations very often used to simulate the metal ion adsorptive kinetics: the first-order Lagergren and the pseudo second-order rate equations [6,33;49]. In this study, the former with $q_{e}(3.37 \mathrm{mg} / \mathrm{g})$ and $R^{2}(0.8233)$ did not well fit experimental data, while the latter fitted the kinetic data with high regression coefficient $\left(R_{P}^{2}, 0.9958\right)$ statistically significant $(p<0.05)$ (Figure 4 and Table 1$)$. As a constant of pseudo second-order rate model, theoretical $q_{e}(6.76 \mathrm{mg} / \mathrm{g})$ was very close to the experimental $q_{e}$ value $(6.79 \mathrm{mg} / \mathrm{g})$. That may be due to that biosorption is the rate-limiting step involving valence forces through sharing or exchanging electrons between biosorbent and sorbate [49]. In most cases (including this work), the former is applicable during the initial $1 / 3$ or $1 / 2$ hour but does not apply well throughout the whole process $[49,50]$. The pseudo secondorder model was also proved most reliable by many researches $[6,33,49,51]$.

\section{Biosorption isotherms}

Biosorption isotherm procedure assumes that all the external biosorption system parameters like $\mathrm{pH}$ and ionic strength are constant [52]. The Langmuir model assumes a monolayer adsorption of which energy is constant and no migration of sorbate molecules in the surface plane [2,5,35]. The Freundlich model is an empirical equation based on adsorption on a heterogeneous surface [36]. The former presented the better adjustment for copper(II) adsorption by dead $C$. lacerata than the latter did (Figure 5). The Langmuir model presented good adjustment with a regression coefficient $\left(R_{L}^{2}\right)$ of $0.9979(p<0.05)$, and Freundlich model also gave a not bad adjustment with a $R_{F}^{2}$ value of $0.9696(p<0.05)$ (Figure 5 and Table 2).

The Langmuir model showed that the maximum capacity of adsorbing copper(II) was $8.31 \mathrm{mg} / \mathrm{g}$, which was assumed that at $\mathrm{pH} 6.0,8.31 \mathrm{mg}$ copper(II) would form a complete monolayer onto the surface of per gram of dead C. lacerata. The Freundlich model had constants of 0.52 for $K_{F}$ value related to the adsorption capacity and 0.56 for $n$ value related to the adsorption intensity.

\section{Comparison of biosorption capacity with other adsorbents}

The maximum biosorption amount $\left(q_{\max }\right)$ depends on fungal species, pretreating methods, the performed parameters. $8.31 \mathrm{mg} / \mathrm{g}$ as the ideal maximum value $\left(q_{\max }\right)$ of copper(II) biosorption by dead C. lacerata was resulted at these conditions: initial copper(II) concentration of

Table 1 Kinetic model constants for copper biosorption by C. lacerata at pH 6 and $25^{\circ} \mathrm{C}$

\begin{tabular}{|c|c|c|c|c|}
\hline Kinetic model & Constants of model & & & \\
\hline First-order Lagergren & $q_{e}=3.37 \mathrm{mg} / \mathrm{g}$ & $k^{\prime}=11.05 \times 10^{-2} h^{-1}$ & $R^{\prime 2}=0.8233$ & $p<0.05$ \\
\hline Pseudo second-order & $q_{e}=6.76 \mathrm{mg} / \mathrm{g}$ & $k_{p}=4.68 \times 10^{-4} \mathrm{~g} / \mathrm{mg} \cdot \mathrm{h}$ & $R_{p}^{2}=0.9958$ & $p<0.05$ \\
\hline
\end{tabular}




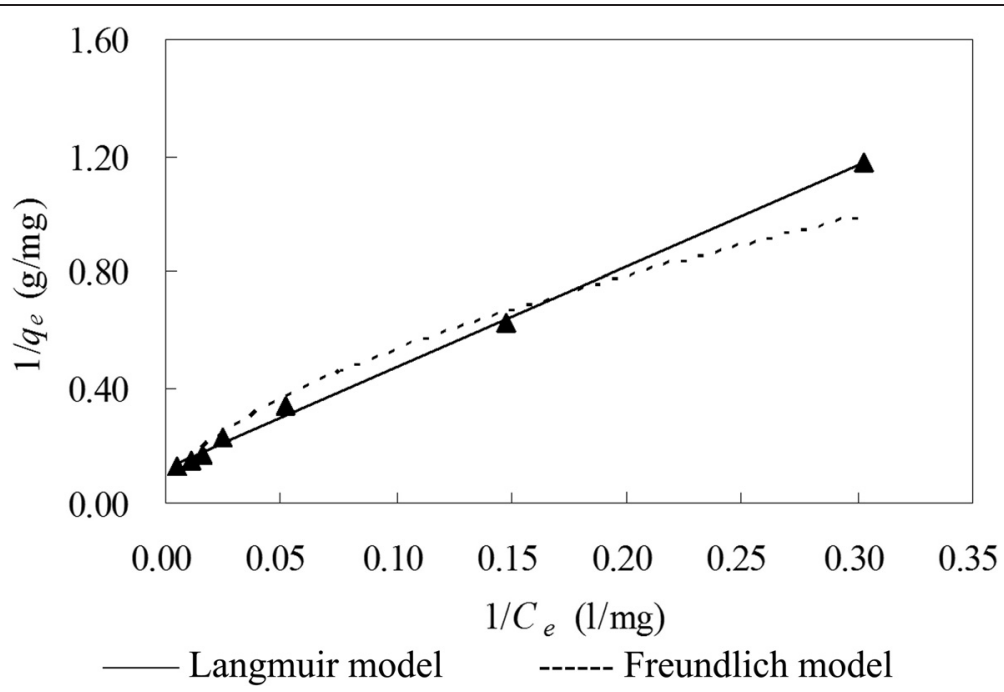

Figure 5 Copper biosorption isotherms by Ceriporia lacerata at pH 6 and $25^{\circ} \mathrm{C}$. Experimental conditions: $\mathrm{pH} 6.0$, initial copper $(\mathrm{II})$ concentration $=$ 5-200 mg/L, volume of copper(II) solution $=100 \mathrm{~mL}$, Ceriporia lacerata dose $=2 \mathrm{~g} / \mathrm{L}$, contact time $=12 \mathrm{~h}$, shaking rate $=150 \mathrm{r} / \mathrm{min}$, temperature $=25^{\circ} \mathrm{C}$.

$100 \mathrm{mg} / \mathrm{L}$, biomass $2 \mathrm{~g} / \mathrm{L}$, solution $100 \mathrm{~mL}$, rotation $150 \mathrm{r} / \mathrm{min}$ and $\mathrm{pH}$ 6.0. The comparison of copper(II) adsorption capacities between dead C. lacerata biomass and other fungal biosorbents is shown in Table 3.

Pretreatments (taking $\mathrm{NaOH}$-boiling and immobilization as examples) could avail copper(II) ions more functional groups to bind. That may be why formaldehyde inactivated $C$. lacerata biomass had lower biosorption capacity than those pretreated fungal biosorbents. Compared with other unpretreated fungal adsorbents, however, biosorption capacity of C. lacerata was relatively high.

\section{Conclusions}

The results illustrated that formaldehyde inactivated Ceriporia lacerata biomass (without acid or alkali treatment for improving adsorption properties) showed a relatively high capacity in removal of copper(II) from aqueous solutions. The optimum operating conditions was proved to be at $\mathrm{pH} 6.0$, contact time of 1 hour, initial copper(II) concentration of $200 \mathrm{mg} / \mathrm{L}$. The pseudo

Table 2 Isotherm model constants for copper biosorption by C. lacerata at $\mathrm{pH} 6$ and $25^{\circ} \mathrm{C}$

\begin{tabular}{lllll}
\hline $\begin{array}{l}\text { Isotherm } \\
\text { models }\end{array}$ & $\begin{array}{l}\text { Constants of } \\
\text { models }\end{array}$ & & & \\
\hline Langmuir & $q_{\max }=$ & $K_{L}=3.45 \times 10$ & $R_{L}^{2}=$ & $p<$ \\
& $8.31 \mathrm{mg} / \mathrm{g}$ & $-2 \mathrm{mg}^{-1}$ & 0.9979 & 0.05 \\
Freundlich & $n=0.56$ & $K_{F}=0.52$ & $R_{F}^{2}=$ & $p<$ \\
& & & 0.9696 & 0.05 \\
\hline
\end{tabular}

second-order adsorptive model gave the best adjustment for copper(II) biosorption kinetics, while the equilibrium data fitted very well to both Langmuir and Freundlich adsorptive isotherm models. Without further acid or alkali treatment for improving adsorption properties, formaldehyde inactivated C. lacerata biomass possesses good biosorption characteristics on copper(II) removal from aqueous solutions. Prospectively, immobilized or further pretreated Ceriporia lacerata biomass has potential to be used as an efficient adsorbent in treatment of heavy metal polluted waters.

Table 3 Copper(II) adsorption capacities (calculated from Langmuir constant $\boldsymbol{q}_{\max }$ ) and experimental parameters of various fungal biosorbents from the literatures

\begin{tabular}{lllll}
\hline Adsorbent & $\mathbf{p H}$ & $\begin{array}{l}\boldsymbol{C}_{\boldsymbol{e}} \\
(\mathbf{m g} / \mathbf{L})\end{array}$ & $\begin{array}{l}\boldsymbol{q}_{\max } \\
(\mathbf{m g} / \mathbf{g})\end{array}$ & References \\
\hline NaOH-treated Aspergillus niger & 6.0 & $0-10$ & 6.35 & {$[6]$} \\
$\mathrm{NaOH}$-treated Botrytis cinerea & 5.0 & $5-300$ & 20.35 & {$[53]$} \\
$\begin{array}{l}\text { Hydrochloric acid-treated waste } \\
\text { beer yeast }\end{array}$ & 5.0 & $\begin{array}{l}3.2- \\
44.8\end{array}$ & 1.46 & {$[54]$} \\
$\begin{array}{l}\text { Immobilized Phanerochaete } \\
\text { chrysosporium }\end{array}$ & 6.0 & $10-500$ & 99.85 & {$[40]$} \\
$\begin{array}{l}\text { Dead Pleurotus pulmonarius } \\
\text { (HCHO inactivated) }\end{array}$ & 4.0 & $5-200$ & 6.20 & {$[10]$} \\
$\begin{array}{l}\text { Dead Schizophyllum commune } \\
\text { (HCHO inactivated) }\end{array}$ & 4.0 & $5-200$ & 1.52 & {$[10]$} \\
$\begin{array}{l}\text { Dead Ceriporia lacerata (HCHO } \\
\text { inactivated) }\end{array}$ & 6.0 & $5-200$ & 8.31 & This study \\
\hline
\end{tabular}




\section{Competing interests}

The authors declare that they have no competing interests.

\section{Authors' contributions}

$X L, A L$ and $M L$ participated in the experimental activity, analysis and interpretation of the data; XT and XL participated in the design of the study and contributed to preparing the manuscript. All authors read and approved the final manuscript.

\section{Acknowledgements}

We are grateful for funding from the Key Project in the National Science and Technology Pillar Program during the Twelfth Five-year Plan Period (2011BAC09B01), the Key National Water Special Project of China (2012ZX07204004-003), the CAS Guiding Strategic Project for Science and Technology (XDA05050204), Guizhou R\&D Program for Social Development (Qiankehe SY [2013]3144, Qiankehe SZ [2014]3036).

\section{Author details}

${ }^{1}$ School of Life Science, Nanjing University, Nanjing 210093, China. ${ }^{2}$ Institute of South China Karst, Guizhou Normal University, Guiyang 550001, China. ${ }^{3}$ Co-Innovation Center for Sustainable Forestry in Southern China, Nanjing Forestry University, Nanjing 210037, China. ${ }^{4}$ The State Key Laboratory Incubation Base for Karst Mountain Ecology Environment of Guizhou Province, Guizhou Normal University, Guiyang 550001, China. ${ }^{5}$ School of Pharmaceutical Sciences, Zhengzhou University, Zhengzhou 450001, China. ${ }^{6}$ Research Center for Karst Wetland Ecology, Guizhou Minzu University, Guiyang 550025, China.

\section{Received: 28 July 2013 Accepted: 14 April 2015}

\section{Published online: 25 April 2015}

\section{References}

1. Sánchez A, Ballester A, Blázquez ML, González F, Muñoz J, Hammaini A. Biosorption of copper and zinc by Cymodocea nodosa. FEMS Microbiol Rev. 1999;23(5):527-36.

2. Çabuk A, Akar T, Tunali S, Gedikli S. Biosorption of $\mathrm{Pb}(\mathrm{II})$ by industrial strain of Saccharomyces cerevisiae immobilized on the biomatrix of cone biomas of Pinus nigra: equilibrium and mechanism analysis. Chem Eng J. 2007;131(1-3):293-300.

3. Pümpel T, Schinner F. Native fungal pellets as a biosorbent for heavy metals. FEMS Microbiol Rev. 1993;11(1-3):159-64.

4. Ahluwalia SS, Goyal D. Microbial and plant derived biomass for removal of heavy metals from wastewater. Bioresource Technol. 2007;98(12):2243-57.

5. Kapoor A, Viraraghavan T. Fungal biosorption - an alternative treatment option for heavy metal bearing wastewaters: a review. Bioresource Technol. 1995;53(3):195-206.

6. Kapoor A, Viraraghavan T, Cullimore DR. Removal of heavy metals using the fungus Aspergillus niger. Bioresource Technol. 1999;70(1):95-104.

7. Say R, Denizl A, Arıca MY. Biosorption of cadmium(II), lead(II) and copper(II) with the filamentous fungus Phanerochaete chrysosporium. Bioresource Technol. 2001;76(1):67-70.

8. Treen-Sears M, Volesky B, Neufeld RJ. Ion exchange/complexation of the uranyl ion by Rhizopus biosorbent. Biotechnol Bioeng. 1984;26(11):809-14.

9. Fourest $E$, Roux JC. Heavy metal biosorption by fungal mycelial by products: mechanisms and influence of pH. Appl Microbiol Biotechnol. 1992;37(3):399-403.

10. Veit MT, Tavares CRG, Gomes-da-Costa SM, Guedes TA. Adsorption isotherms of copper(II) for two species of dead fungi biomass. Process Biochem. 2005;40(10):3303-8.

11. Tobin JM, Cooper DG, Neufeld RJ. Uptake of metal ions by Rhizopus arrhizus biomass. Appl Environ Microbiol. 1984;47(4):821-4.

12. De Rome L, Gadd GM. Copper adsorption by Rhizopus arrhizus, Cladosporium resinae and Penicillium italicum. Appl Microbiol Biotechnol. 1987;26(1):84-90.

13. Özer A, Ekiz HI, Özer D, Kutsal T, Çağlar A. A stage purification process to remove heavy metal ions from wastewater using Rhizopus arrhizus. Process Biochem. 1991;32(44):319-26.

14. Bahadir T, Bakan G, Altas L, Buyukgungor $H$. The investigation of lead removal by biosorption: an application at storage battery industry wastewaters. Enzyme Microb Technol. 2007;41(1-2):98-102.
15. Townsley CC, Ross IS. Copper uptake in Aspergillus niger during batch growth and in nongrowing mycelial suspension. Exp Mycol. 1986;10(4):281-8.

16. Huang $\mathrm{C}$, Huang $\mathrm{CP}$, Morehart AL. Proton competition in $\mathrm{Cu}(\mathrm{II})$ adsorption by fungal mycelia. Water Res. 1991;25(11):1365-75.

17. Rostami K, Joodaki MR. Some studies of cadmium adsorption using Aspergillus niger, Penicillium austurianum, employing an airlift fermenter. Chem Eng J. 2002;89(1-3):239-52.

18. Niu H, Xu XS, Wang JH. Removal of lead from aqueous solutions by Penicillium biomass. Biotechnol Bioeng. 1993;42(66):785-7.

19. Volesky B, May-Phillips HA. Biosorption of heavy metals by Saccharomyces cerevisiae. Appl Microbiol Biotechnol. 1995;42(5):797-806.

20. Baldrian P. Interactions of heavy metals with white-rot fungi. Enzyme Microb Technol. 2003;32(1):78-91.

21. Bayramoğlu G, Bektaş S, Arıca MY. Biosorption of heavy metal ions on immobilized white-rot fungus Trametes versicolor. J Hazard Mater. 2003;B101(3):285-300.

22. Suhara H, Maekawa N, Kaneko S, Hattori T, Sakai K, Kondo R. A new species, Ceriporia lacerata, isolated from white-rotted wood. Mycotaxon. 2003;86:335-47.

23. Suhara H, Daikouku C, Takata H, Suzuki S, Matsufuji Y, Sakai K, et al. Monitoring of white-rot fungus during bioremediation of polychlorinated dioxin-contaminated fly ash. Appl Microbiol Biotechnol. 2003;62(5-6):601-7.

24. Kim G, Lim Y, Song Y, Kim J. Decay fungi from playground wood products in service using $28 \mathrm{~S}$ rDNA sequence analysis. Holzforschung. 2005;59(44):459-66.

25. Cui B, Wei Y, Dai Y. Polypores from Zijin Mountain, Jiangsu province. Mycosystema. 2006;25(1):9-14.

26. Xu L, Zhu Y, He XB, Han GM, Tian XJ. Evaluation of a new fungus Ceriporia lacerate strain P2 -its ability to decolorize Alizarin Red and Methyl Orange. World J Microbiol Biotechnol. 2008;24(12):3097-104.

27. Chowdhary A, Agarwal K, Kathuria S, Singh PK, Roy P, Gaur SN, et al. Clinical significance of filamentous basidiomycetes illustrated by isolates of the novel opportunist Ceriporia lacerata from the human respiratory tract. J Clin Microbiol. 2013:51(2):585-90.

28. Kim JH, Park YK, Kim JE, Lee SP, Kim BC, Jang BC. Crude extract of Ceriporia lacerata has a protective effect on dexamethasone-induced cytotoxicity in INS-1 cells via the modulation of PI3K/PKB activity. Int J Mol Med. 2013;32(1):179-86.

29. Singh SK, Doshi A, Pancholy A, Pathak R. Biodiversity in wood-decay macro-fungi associated with declining arid zone trees of India as revealed by nuclear rDNA analysis. Eur J Plant Pathol. 2013;136(2):373-82.

30. Lee EJ, Lee SP. Novel bioconversion of sodium glutamate to $\gamma$-Amino butyric acid by co-culture of Lactobacillus plantarum K154 in Ceriporia lacerata culture broth. Food Sci Biotechnol. 2014;23(6):1997-2005.

31. Kim MJ, Kim JJ, Kim GH. Metal tolerance and sorption potential of indigenous basidiomycetous fungi. In: Proceeding of Korean Timber Engineering Society; 2011. p. 88-89.

32. Ho YS, Wase DAJ, Foster CF. Kinetic studies of competitive heavy metal adsorption by sphagnum peat. Environ Technol. 1996;7(1):71-7.

33. Benquella $B$, Benaissa $H$. Cadmium removal from aqueous solution by chitin: kinetic and equilibrium studies. Water Res. 2002;36(10):2463-74.

34. Pino GH, de Mesquita LMS, Torem ML, Pinto GAS. Biosorption of cadmium by green coconut shell powder. Miner Eng. 2006;19(5):380-7.

35. Langmuir I. The adsorption of gases on plane surfaces of glass, mica and platinum. J Am Chem Soc. 1918;40(9):1361-403.

36. Sağ Y, Kaya A, Kutsal T. The simultaneous biosorption of $\mathrm{Cu}(\mathrm{II})$ and $\mathrm{Zn}(\mathrm{II})$ on Rhizopus arrhizus: application of the adsorption models. Hydrometallurgy. 1998;50(3):297-314.

37. Aksu Z, Gönen F, Demircan Z. Biosorption of chromium(VI) ions by Mowital $\mathrm{B} 30 \mathrm{H}$ resin immobilized activated sludge in a packed bed: comparison with granular activated carbon. Process Biochem. 2002;38(2):175-86.

38. Galli E, Mario FD, Rapanà P, Lorenzoli P, Angelini R. Copper biosorption by Auricularia polytricha. Lett Appl Microbiol. 2003;37(2):133-7.

39. Ozer A, Ozer E. Comparative study of the biosorption of $\mathrm{Pb}(\mathrm{II}), \mathrm{Ni}(\mathrm{II})$ and $\mathrm{Cr}(\mathrm{VI})$ ions onto S. cerevisiae: determination of biosorption heats. J Hazard Mater. 2003;B100(1-3):219-29.

40. Iqbal M, Edyvan RGJ. Biosorption of lead, copper and zinc ions on loofa sponge immobilized biomass of Phanerochaete chrysosporium. Miner Eng. 2004;17(2):217-23. 
41. Tewari N, Vasudevan P, Guha BK. Study on biosorption of $\mathrm{Cr}(\mathrm{VI})$ by Mucor hiemalis. Biochem Eng J. 2005;23(2):185-92.

42. Asmal M, Khan AH, Ahmad S, Ahmad A. Cole of sawdust in the removal of copper(II) from industrial wastes. Water Res. 1998;32(10):3085-91.

43. Huang CP, Ostovic FB. Removal of cadmium(II) by activated carbon adsorption. J Environ Eng. 1978;104(5):863-78.

44. Reed $\mathrm{BE}$, Arunachalam $\mathrm{S}$. Use of granular activated carbon columns for lead removal. J Environ Eng. 1994;120(2):416-36.

45. Beolchini F, Pagnanelli F, Reverberi AP, Vegliò F. Copper biosorption onto Rhizopus oligosporus: pH-edge tests and related kinetic and equilibrium modeling. Int Eng Chem Res. 2003;42(20):4881-7.

46. Li XN, Xu QY, Han GM, Zhu WQ, Chen ZH, He XB, et al. Equilibrium and kinetic studies of copper(II) removal by three species of dead fungal biomasses. J Hazard Mater. 2009;165:469-74.

47. Nuhoglu Y, Oguz E. Removal of copper(II) from aqueous solutions by biosorption on the cone biomass of Thuja orientalis. Process Biochem. 2003;38:1627-31.

48. Gabriel J, Baldrian P, Hladíková K, Háková M. Copper sorption by native and modified pellets of wood-rotting basidiomycetes. Lett Appl Microbiol. 2001;32(3):194-8.

49. Yan C, Wang S, Zeng A, Jin $X$, Xu Q, Zhao J. Equilibrium and kinetics of copper(II) biosorption by Myriophyllum spicatum L. J Environ Sci. 2005;17(6):1025-9.

50. Taty-Costodes VC, Fauduet H, Porte C, Delacroix A. Removal of Cd(II) and $\mathrm{Pb}$ (II) ions from aqueous solutions by adsorption onto sawdust of Pinus sylvestris. J Hazard Mater. 2003;B105(1-3):121-42.

51. Kapoor A. Removal of heavy metals from aqueous solution by Aspergillus niger. PhD Thesis. Regina: University of Regina;1992.

52. Volesky B. Biosorption and me. Water Res. 2007;41 (18):4017-29.

53. Akar T, Tunali S. Biosorption performance of Botrytis cinerea fungal by-products for removal of $\mathrm{Cd}(\mathrm{II})$ and $\mathrm{Cu}(\mathrm{II})$ ions from aqueous solutions. Miner Eng. 2005;18(11):1099-109.

54. Han R, Li H, Li Y, Zhang J, Xiao H, Shi J. Biosorption of copper and lead ions by waste beer yeast. J Hazard Mater. 2006;B137(3):1569-76.

\section{Submit your next manuscript to BioMed Central and take full advantage of:}

- Convenient online submission

- Thorough peer review

- No space constraints or color figure charges

- Immediate publication on acceptance

- Inclusion in PubMed, CAS, Scopus and Google Scholar

- Research which is freely available for redistribution 